\title{
Hygienic quality of stem fractions of mechanically processed fibre hemp and linseed
}

\author{
Hanna-Riitta Kymäläinen, Minna Nykter, Mikko Hautala and Anna-Maija Sjöberg \\ Department of Agrotechnology, PO Box 28 (Koetilantie 3), FI-00014 University of Helsinki, \\ e-mail: hanna-riitta.kymalainen@helsinki.fi
}

\begin{abstract}
Bast fibre is the most important fraction of bast fibre plants for technical products, i.e. thermal insulations and packaging materials. The hygienic quality of the various fractions of bast fibre plants is of interest in thermal insulations, because it may affect the quality of indoor air. Packaging materials may be associated e.g. with foodstuffs, which highlights the importance of hygienic quality. The aim of this study was to screen the hygienic quality, determined as microbial content, of mechanically fractionated fibre hemp and linseed plants harvested in the autumn before frost, after early frost and in spring. In addition, the possible correlation between microbes and ash was investigated. Two plant species, fibre hemp and linseed were studied. The plants were cultivated in Siuntio in southern Finland during the years 2002 and 2003, harvested in autumn or in spring and mechanically fractionated. The microbial contents of the fractions were examined by measuring the total number of microbes using Hygicult ${ }^{\circledR}$ growing slides. The microbial content of fractions of fibre hemp and linseed varied between $10^{3}$ and $10^{9} \mathrm{cfu} / \mathrm{g}_{\mathrm{dw}}$. The fibre of hemp harvested after early frost or in spring had the lowest amount of moulds, but during winter and spring the amounts of bacteria and yeasts increased in hemp. Mechanically separated fibre and shive contained less microbes than the stalk. Ash contents of all examined samples of stems and stem fractions varied between $1 \%$ and $14 \%$. The fibre after fractionating had a lower ash content (2.3-3.3\%) than that of stems (4.4-6.9\%) harvested in the autumn. The ash content of stem and shive decreased to $1.6 \%$ during winter, the ash content of fibre being even somewhat lower $(0.9 \%)$. No correlation was observed between the contents of microbes and ash.
\end{abstract}

Key words: hygienic quality, microbes, ash, bast fibres, linseed, fibre hemp, Linum usitatissimum, Cannabis sativa

\section{Introduction}

Recent research of bast fibre plants has been focused on non-textile applications. Bast fibres may be used for building materials, e.g. thermal insula- tions (Ringleb and Schulz 1996, Koivula et al. 2005), packaging materials (Tavisto et al. 2001) and composites (Hepworth et al. 2000, Hautala et al. 2004). Typical applications for shives as main or secondary component are building materials (e.g. shive-boards, thermal insulations) or horse- 
Kymäläinen, H.-R. et al. Hygienic quality of hemp and linseed stem fractions

bedding, but shive has also been used as a component of packaging materials (Tavisto et al. 2001). Limits for microbial quality of fibre materials have been given e.g. in the legislation of thermal insulations (STM 2003).

Linseed and hemp are annual bast fibre plants, from which the stem must be retted and bast separated from woody core using microbial, chemical, thermal or mechanical methods (Sultana 1992). Consideration of microbiological contamination connected e.g. to the retting process has been presented in some previous studies, the focus of which however has been on other aspects. According to the study by Hepworth et al. (2000), the retting process causes microbiological contamination of the fibre as a side effect. If excessive lodging occurs in the field due e.g. to too low plant density, fungal infections may occur (Struik et al. 2000). Hobson et al. (2001) suggested low amounts of retting microorganisms to be considered as marketing advantages of bast fibres e.g. for health and safety reasons. In addition to their effects on the hygienic quality, microorganisms also affect various properties of the fibre, such as strength, porosity and colour.

The inorganic content of a plant is usually characterized by its ash content, which is an approximate measure of the mineral salts and other inorganic matter in the fibre after combustion (Han and Rowell 1997). With development of new harvesting and processing techniques of fibre plants, contamination with soil and sand has been discussed and found to increase the ash content of plants (Kymäläinen et al. 2002). Due to the microbial content of soil, contamination with soil is a potential risk for hygienic quality in products made from plant materials, such as thermal insulations (Koivula et al. 2005) and packaging materials (Sjöberg et al. 2002). Contamination with soil may also cause problems in processing systems (Kymäläinen et al. 2004).

The variation of microbial quality of linseed plant during the growing season has been studied earlier by e.g. Saharan and Singh (1985) and Vloutoglou et al. (1995). In a study by Koivula et al. (2004), changes of microbial quality of linseed and hemp during the growing season were studied.
However, there is no published quantitative information on the hygienic quality of fractionated stems of bast fibre plants. In this study the fibre hemp and linseed plants were cultivated, harvested before and after early frost in autumn and after frost-retting in spring, and fractionated. The aim of the study was to examine the microbial quality determined as microbial content of mechanically processed fibre hemp and linseed plant fractions and to investigate correlations between microbial and ash contents of the fractions. In addition, the difference in hygienic quality between the separated fibre and the stems in the field before harvest was evaluated.

\section{Material and methods}

\section{Cultivation and harvesting of the plants}

In this study two plant species were investigated: fibre hemp (Cannabis sativa L.), var. Uso and linseed (Linum usitatissimum L.), var. Helmi. The plants were cultivated and harvested in Siuntio in southern Finland during the years 2002 and 2003. The plants were cultivated according to common farming practices in Finland (Hakala and Hongisto 1994, Sankari 1998). The growing season of 2002 was relatively cool and moist: average temperature rarely exceeded $20^{\circ} \mathrm{C}$ and average relative humidity of the air was over $80 \%$ most of the time. The climatic conditions and development of microbial quality of the plants during the growing season were reported in detail by Koivula et al. (2004). The winter season 2002-2003 was very cold, with temperatures below $-20^{\circ} \mathrm{C}$ for some periods.

The stalks were harvested by cutting with garden shears, threshing or mowing (Table 1) with a mower just before or around noon of the harvest day. Stalks were immediately transported to a drying room $\left(\mathrm{T} \sim 50^{\circ} \mathrm{C}, \mathrm{t}=7\right.$ days) with a delay between harvest and drying of approximately three to four hours. The plants and details of harvesting and sampling are presented in Table 1 . The dried stems were stored sealed in a plastic foil wrapping 
Vol. 14 (2005): 143-153.

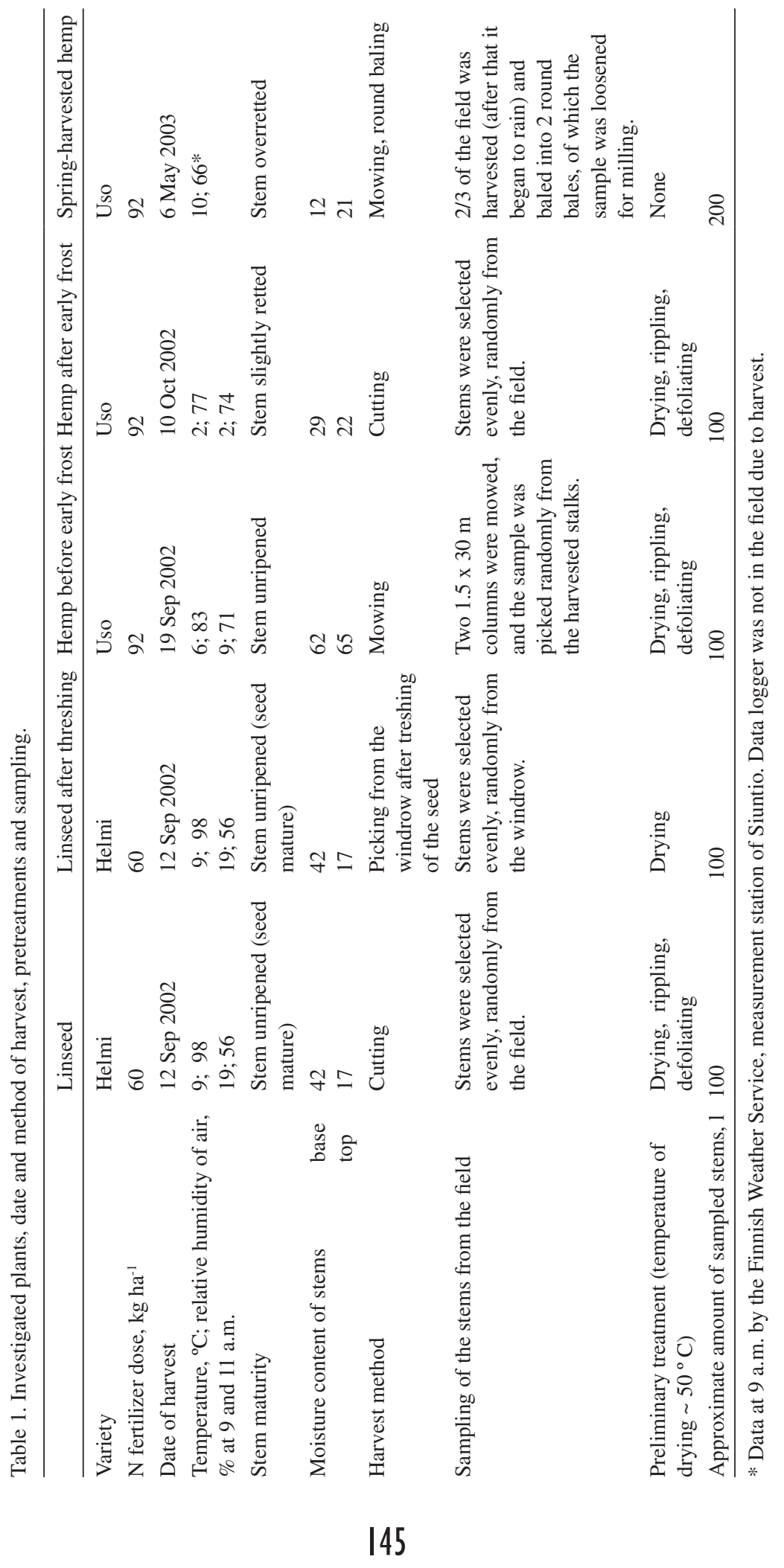


in a storeroom $\left(\mathrm{T} \sim 18^{\circ} \mathrm{C}\right)$ for one to three months before fractionation.

\section{Fractionation}

The dried, unprocessed stalk and four fractions (fibre, shive, dust, leaves and seeds or seed capsules) of hemp and linseed were studied. The pilot fractionating method, introduced and described in detail by Kymäläinen et al. (2001), consisted of drying the stalks, milling the stems with a hammer mill, separating particles from an air stream in a cyclone, and separating fibre and shive with a screening drum and a sieve vibrator (Fig. 1). The separated fractions were stored in plastic buckets at room temperature $\left(\sim 22^{\circ} \mathrm{C}\right)$ before measurements of microbes and ash.

\section{Microbial content of the fractions}

The microbial contents of the fractions were examined by measuring the total number of microbes using Hygicult ${ }^{\circledR}$ Y\&F (yeasts and fungi) and TPC (total bacteria) growing slides (Orion Diagnosti- ca). This method was introduced for samples of bast fibre plants by Koivula et al. (2004). The Hygicult ${ }^{\circledR}$ TPC dipslides were validated against swabbing and control plate methods and the results were at the same level (Salo et al. 2000). Samples (Fig. 1) were randomly picked from the fraction container. A separate sample for moisture content measurement was taken at the same time. An amount of $100 \mathrm{ml}$ of saline solution $(\mathrm{NaCl} 0.9 \%)$ was added to a weighed dry sample ( $5 \mathrm{~g}$, except for the dust samples $1 \mathrm{~g}$ because of their limited amount). After 30 minutes of extraction, samples were homogenized for five minutes in a Stomacher 400 Circulator (Merck Eurolab, 230 rpm). An amount of $50 \mu \mathrm{l}$ of the liquid was pipetted onto one side of a Hygicult ${ }^{\circledR}$ slide. Slides were incubated for 4 days at room temperature $\left(\sim 25^{\circ} \mathrm{C}\right)$, after which the colonies were counted and the numbers of microbes were counted as colony forming units per gram of a dry fraction $\left(\mathrm{cfu} / \mathrm{g}_{\mathrm{dw}}\right)$.

\section{Ash content of the fractions}

The ash contents of the fractions were measured according to a TAPPI standard (T $211 \mathrm{om}-85)$ with

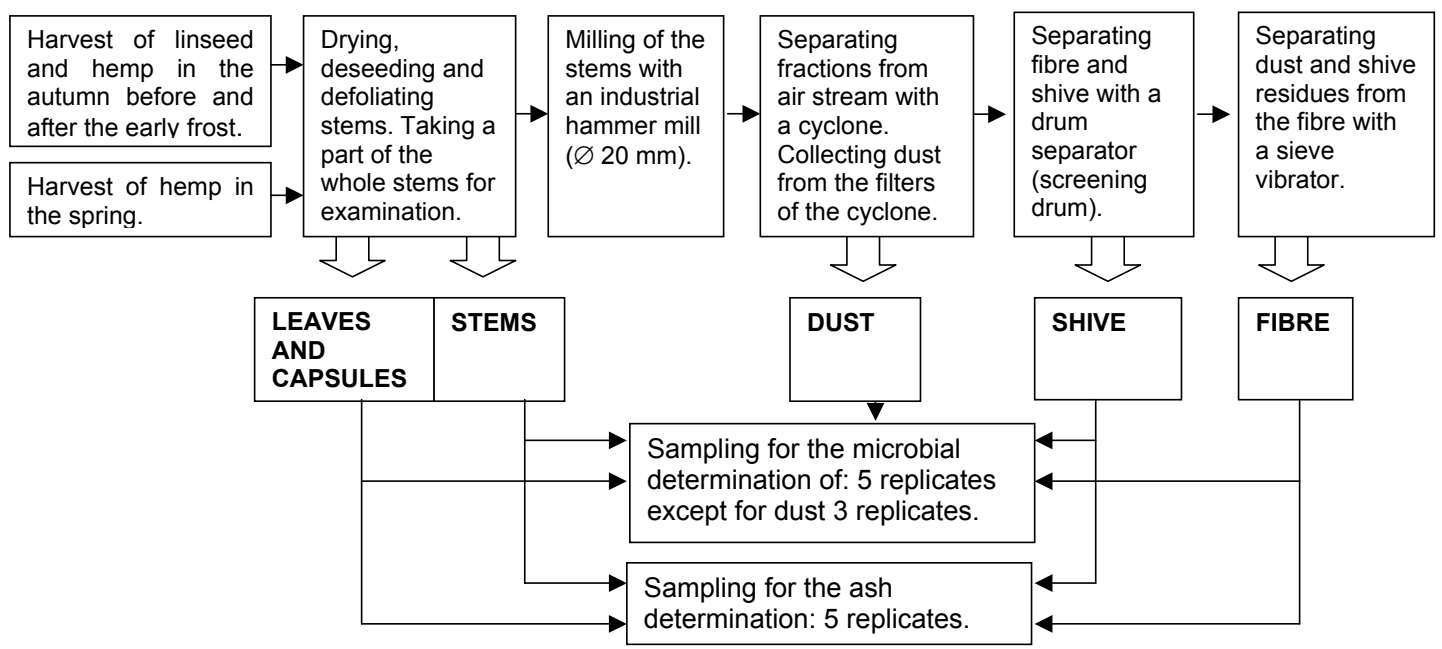

Fig. 1. Pilot method for fractionation of stems of bast fibre plants and sampling of the fractions for the hygienic measurements. 
Vol. 14 (2005): 143-153.

five replicates (the mass of one replicate was $2.5 \mathrm{~g}$ ) with the minor adjustment of using crucibles without lids. Samples (Fig. 1) were randomly picked from the container. The temperature of the furnace while transferring the sample into the muffle furnace was $275^{\circ} \mathrm{C} \pm 25^{\circ} \mathrm{C}$ and the ashing temperature $575^{\circ} \mathrm{C} \pm 25^{\circ} \mathrm{C}$. A temperature of $575^{\circ} \mathrm{C} \pm 25^{\circ} \mathrm{C}$ is commonly used for combustion (Han and Rowell 1997), but other temperatures, e.g. $900^{\circ} \mathrm{C}$, are also used (Archibald 1992).

Variance analysis (one-way ANOVA, Tukey's post hoc test of significance) of the SPSS statistical tool was used to examine differences between the mean microbial contents and ash of the fractions harvested at different times. Bivariate correlation analysis (Pearson's correlation coefficients, twotailed test of significance) was used to examine the possible correlation between moulds, yeasts and total bacteria, and between ash and microbial contents.

\section{Results}

The moisture contents of the dried samples in the microbial and ash determinations, measured from separate samples that were dried in an oven at $103^{\circ} \mathrm{C}$ for $24 \mathrm{~h}$, were between 5 and $9 \%$ (wet basis; w.b.).

\section{Microbial contents of the fractions}

The microbial contents of fractions of fibre hemp and linseed varied between $10^{3}$ and $10^{9} \mathrm{cfu} / \mathrm{g}_{\mathrm{dw}}$ (Fig. 2). The amounts of moulds, yeasts and total bacteria were at the same level in the linseed stems cut before threshing of the seed and in the stems collected from the windrow after threshing (Fig. 2 ). Therefore only the results of the cut stems are presented in Figure 3.

Before early frost, the amounts of the moulds, yeasts and total bacteria were higher in linseed than in hemp (Fig. 3) $(\mathrm{P}<0.001, \mathrm{P}<0.05$ and $\mathrm{P}<$ 0.01 , respectively). The fibre of hemp harvested after early frost or in spring had the lowest amount of moulds. The difference between the fractions harvested before and after early frost was statistically significant $(\mathrm{P}<0.05)$. The mould contents of the fibre and shive fractions were lower than that of stem $(\mathrm{P}<0.001)$. The mould content of the hemp stems was highest in spring (Fig. 3a).

During winter and spring the amount of yeasts increased in hemp $(\mathrm{P}<0.01)$. There were less yeasts in the fibre and shive than in the stems $(\mathrm{P}<$ 0.01) (Fig. 3b).

The amounts of bacteria of flax and hemp harvested at different times differed statistically significantly from each other $(\mathrm{P}<0.05$ between all harvesting times). The amount of total bacteria was lower in fibre and shive than in stems of linseed and hemp before frost and in hemp after winter $(\mathrm{P}<0.01)$. During the winter and spring period there was a clear increase in the amount of bacteria, especially in the stems but also in the fibre and shive fractions (Fig. 3c).

There was no general correlation between the amounts of moulds, yeasts and total bacteria. However, some of the correlations shown in Table 2 were statistically significant.

\section{Ash content of the fractions}

The seed, capsule and leaf fractions of hemp had the highest (>10\%) ash contents (Fig. 4). The difference between this fraction and all other fractions was statistically significant $(\mathrm{P}<0.001)$. The cut stems had the highest ash content of the linseed samples. Threshing, milling and sieving decreased the ash content of linseed from $5.7 \%$ (average of stems) to $3.2 \%$ (stems from the windrow) and 3.3$3.4 \%$ (fibre and shive). Similarly, the separation decreased the ash content of hemp from 4.4-6.9\% (stems before and after frost, respectively) to 2.3$2.5 \%$ (hemp fibre and shive samples before and after frost). Even when the ash contents of the fibre and shive fractions were lower than those of the stems, only the fibre fractions differed statistically significantly $(\mathrm{P}<0.05)$ from stem due to the differences between the two plants. The difference between the fibre and shive samples at one harvest time was negligible $(\mathrm{P}>0.05)$. As shown in Figure 

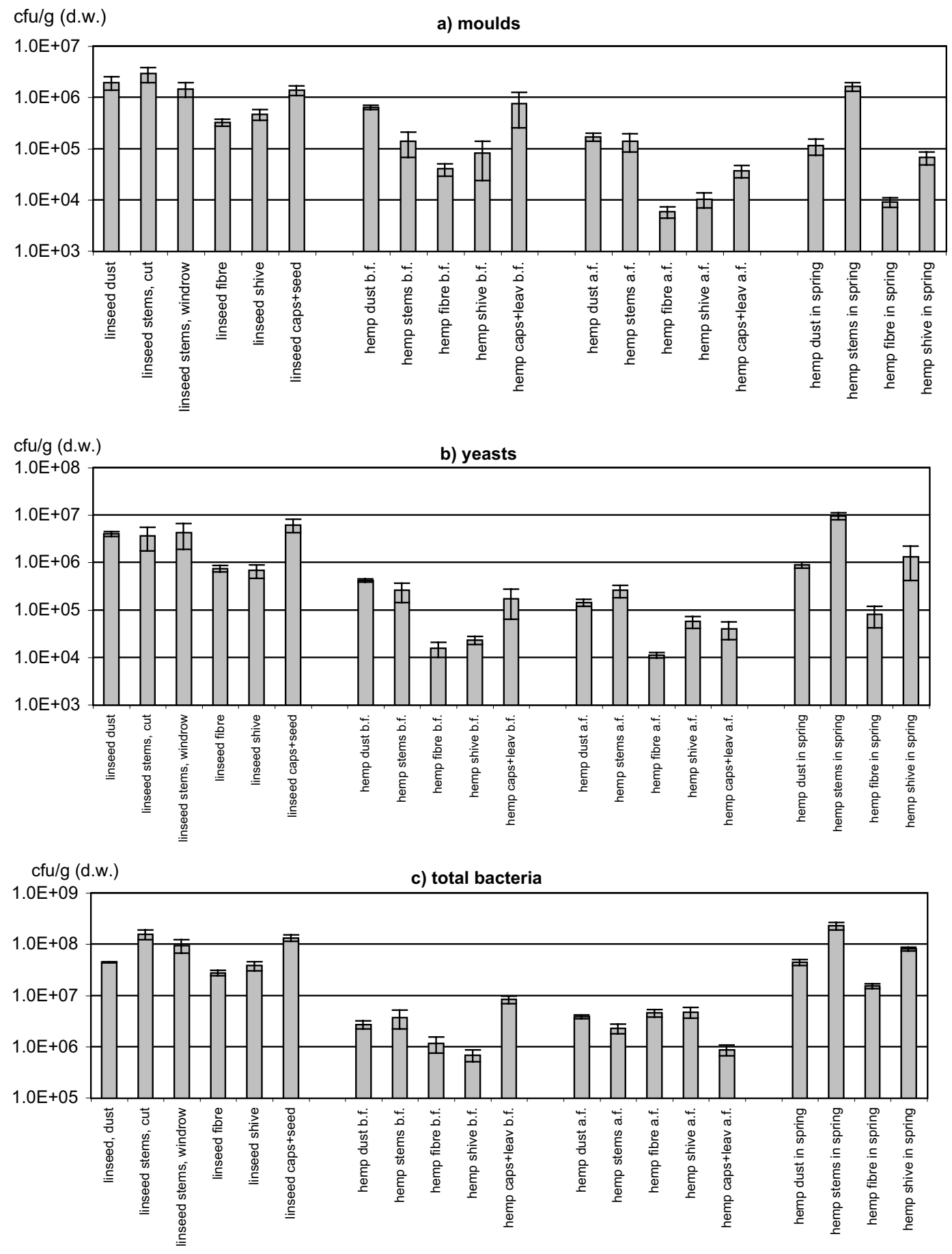

Fig. 2. Amounts of microbes (cfu/g $\left.\mathrm{g}_{\mathrm{dw}}\right)$ in dried and processed fractions at different harvest times: before frost (hemp b.f., linseed), after early frost (hemp a.f.) and in spring (hemp), a) moulds, b) yeasts, c) total bacteria. Columns are means of three (dust samples) or five replicates (other samples), bars in columns are standard errors of means of the replicates $( \pm \mathrm{SE})$. d.w. $=$ dry weight. 
Vol. 14 (2005): 143-153.
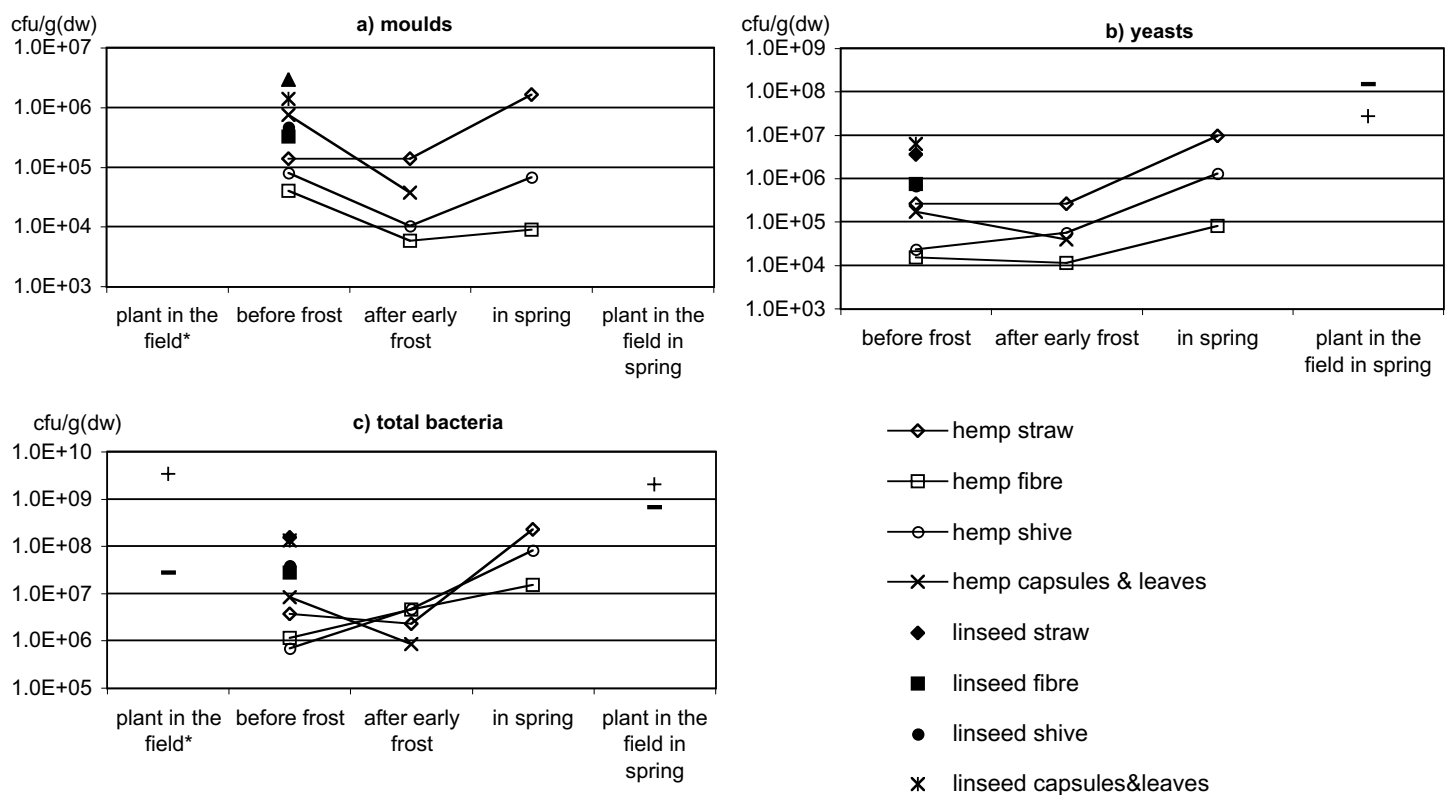

Fig. 3. Amounts of microbes (cfu/g $\mathrm{g}_{\mathrm{dw}}$ ) in dried and processed fractions of hemp and linseed at different harvest times: before frost (hemp b.f., linseed), after early frost (hemp a.f.) and in spring (hemp), a) moulds, b) yeasts, c) total bacteria. Results are means of five replicates.

* fractions before harvest in the field in autumn (data from Koivula et al. 2004) and in spring

Table 2. Pearson's correlation coefficients between moulds, yeasts, total bacteria and ash (both plant species and all fractions included). Harvest times were analysed separately.

\begin{tabular}{lllccc}
\hline & Harvest time & Ash & Moulds & Yeasts & Total bacteria \\
\hline Ash & Before frost & 1 & 0.220 & -0.079 & 0.022 \\
& After early frost & 1 & 0.418 & 0.226 & $-0.996^{* *}$ \\
& Spring & 1 & 0.528 & 0.601 & 0.733 \\
Moulds & Before frost & 0.220 & 1 & $0.713^{*}$ & $0.980^{* *}$ \\
& After early frost & 0.418 & 1 & $0.971^{*}$ & -0.487 \\
Yeasts & Spring & 0.528 & 1 & 0.996 & 0.965 \\
& Before frost & -0.079 & $0.713^{*}$ & 1 & $0.999^{* *}$ \\
Total bacteria & After early frost & 0.226 & $0.971^{*}$ & 1 & -0.294 \\
& Spring & 0.601 & 0.996 & 1 & 0.984 \\
& Before frost & 0.022 & $0.980^{* *}$ & $0.999 * *$ & 1 \\
\hline
\end{tabular}

* Correlation is significant at the 0.05 level (2-tailed).

** Correlation is significant at the 0.01 level (2-tailed).

4, the ash contents of the spring-harvested samples were the lowest $(0.9-1.6 \%)$, and the differences between the ash contents of the fractions harvested in spring also differed statistically from those har- vested in autumn $(\mathrm{P}<0.01)$. In most cases there was no significant correlation between the ash and microbial contents of the fractions (Table 2). The only exception was the correlation coefficient of 


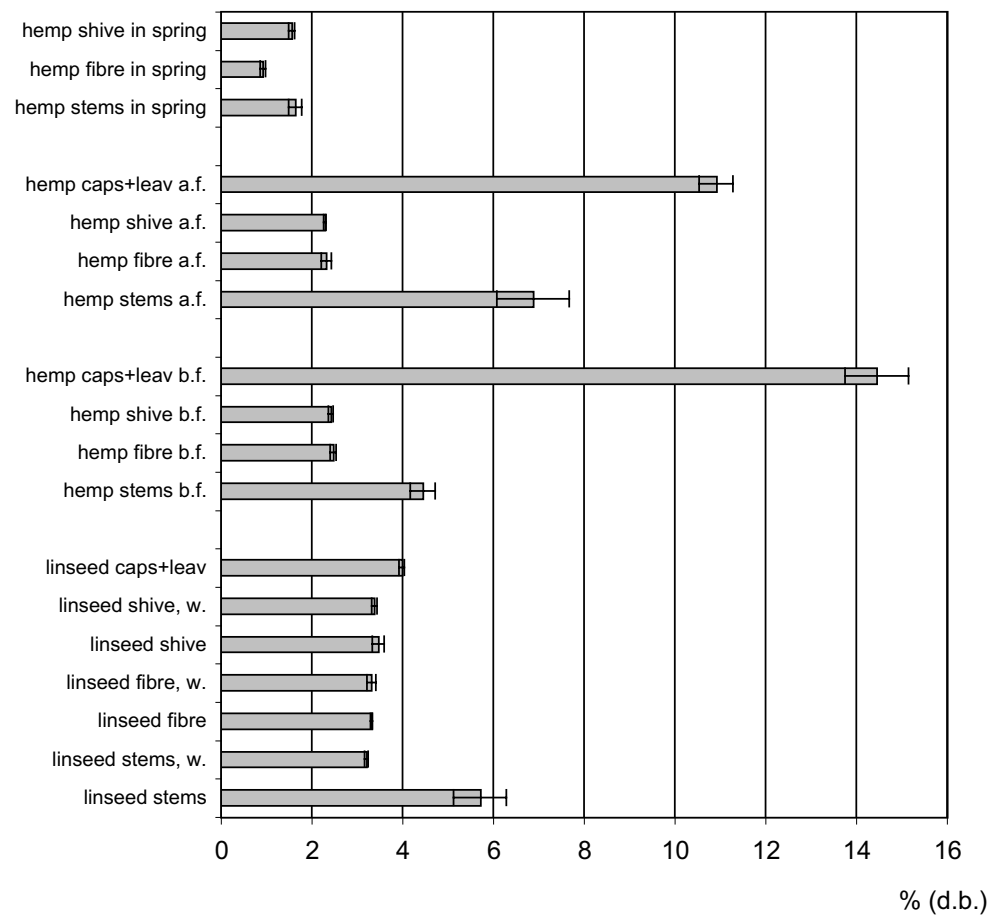

Fig. 4. Ash contents of fractions (\% dry basis; d.b.). Columns are means of five replicates, bars in columns are standard errors of means of the replicates $( \pm \mathrm{SE})$.
0.996 between ash and total bacteria (fractions harvested after early frost).

\section{Discussion}

In the present study, the amount of moulds was on the same level in the cut, dry hemp stems (Fig. 3) as in the living plant at the end of the growing season in autumn (Koivula et al. 2004). By processing and mechanical separation, it was possible to produce fibre containing somewhat less moulds and bacteria than the plant in the field (Fig. 2). It is possible that the separation process itself affected this result, but more probably the microbial content is higher in the surface than in the inner parts of the plant. The industrial processes for producing raw material for e.g. packages or loose-fill insulations are similar to the present pilot process.

According to the recommendations of the Ministry of Social Affairs and Health in Finland, the amount of fungal spores should not exceed $10^{4}$ $\mathrm{cfu} / \mathrm{g}$, and the amount of bacteria should be below $10^{5} \mathrm{cfu} / \mathrm{g}$ in material samples taken from buildings (STM 2003). However, the focus of these limits is on other building materials than thermal insulations, and the information is thus only indicative for the fibre materials of the present study. On the basis of the amount of fungi, the hemp fibre harvested after early frost or in spring in this study could be accepted, but the amount of bacteria was clearly higher than the recommendation. In our study, the moisture contents of the samples were between $5 \%$ and $9 \%$ (w.b.) but e.g. in field conditions the moisture content of bast fibre plants may be as high as $85 \%$ (Koivula et al. 2004). Our results were expressed per dry weight, but if they were converted to fresh weight, the variation range would remain almost the same (based on a moisture content $9 \%$ ) or approximately tenfold lower (moisture content 85\%), meaning that the fibre harvested in spring would also be suitable.

Frost retting is a method in which seeds are harvested in autumn and the standing stalks are left 
Vol. 14 (2005): 143-153.

to ret in the field for winter. Alternation of thawing and freezing during winter separates fibres from stems (Pasila 2000). The stems of linseed were very short and partly bent or lodged and thus not ideal for frost retting, and therefore only hemp stalks were sampled after early frost and harvested in the spring of the year 2003. In the present study, the early frost decreased the amount of total bacteria in those parts of hemp containing tissues of outer layers (stem, capsules), whereas the amount of total bacteria decreased in the inner fractions (fibre and shive). The outer surface of a plant may prevent microbial invasion of the tissues in living plants (Adams and Moss 2002) and it may have affected the lower microbial content of the fibre and shive fractions compared to the whole stalk. Slow freezing or recrystallization of water leads to cellular damage and thus release of cell constituents, causing drip losses during thawing. The drip losses provide substrates for enzyme activity and microbial growth (Fellows 2000), which was seen as changes in the amount of total bacteria in the present study. In kenaf-growing areas, early frost has been found to be a problem because it kills the crop before harvest and the plants develop fungus or mildew.

According to the results of this study, threshing of linseed did not affect the microbial content of the stems. In general, all agricultural and processing machines are potential contamination sources for the plant materials being processed. Agricultural dust consists of inorganic matter, i.e. minerals from rock or soil or silicates from plants, and organic substances, which are biologically more active than inorganic dusts (Donham 1986).

Unlike cellulose and lignin contents, which increase with plant age (Struik et al. 2000, Keller et al. 2001), Overbeke and Mazingue (1949) did not find hemicellulose and ash contents to have a systematic progression with age. According to our earlier studies (Kymäläinen et al. 2002), the ash content of mechanically fractionated flax fibre was $2.9-3.8 \%$ and that of hemp fibre was $2.2-2.8 \%$, and in most cases the lowest levels were in frostretted samples. The frost-retted samples also had the lowest ash contents in the present study. This is probably due to changes in the chemical composi- tion (decrease of mineral substances) of the stem during retting. Mineral substances, e.g. K, Na, Ca, $\mathrm{Zn}$ and $\mathrm{Fe}$, probably leak out from the stem during retting (Sharma 1992). The ash content of bast fibre of linseed produced using a different method than in the present study was $5 \%$ and that of hemp $0.8 \%$ (Han and Rowell 1997), and that of flax shive was $3.1-5.5 \%$ (unretted) and 1.2-2.0\% (retted) (Sharma 1992). In the present study, the harvesting and processing was carried out with relatively clean techniques. By contrast, contamination of fibres with soil in various other production methods has been found to increase the ash level much more than was measured in this work (Kymäläinen et al. 2002). Our mechanical pilot process included several steps during which impurities such as dust were removed from fibre and shive. The possible inorganic contaminants were at least partly removed from the stem, which in this study resulted in relatively low ash contents of the fibre and shive compared to the ash content of the stem. This may explain why there was no correlation between the contents of microbes and ash in this study.

\section{Conclusion}

The microbial content of the fractions of fibre hemp and linseed varied between $10^{3}$ and $10^{9} \mathrm{cfu} /$ $\mathrm{g}_{\mathrm{dw}}$. The levels exceeding $10^{5} \mathrm{cfu} / \mathrm{g}$ may be too high for certain applications such as building materials. The fibre of hemp harvested after early frost or in spring had the lowest amount of moulds, but during winter and spring the amount of bacteria and yeasts increased in hemp. Mechanically separated fibre and shive contained less microbes than the stalk. It was shown that the microbial content of fibre cannot be predicted reliably from the microbial content of stems in the field. Fractionation decreased the ash content of stems harvested in the autumn. The ash contents of the frost-retted fractions were the lowest. In this study no correlation was observed between the microbial and ash contents. 
Acknowledgements. We are grateful to agroforestry students Ari Klemola, Janne Pirilä, Jukka Ruunaniemi and Asaye Talibachew in the Flax Team of the Department of Agricultural Engineering and Household Technology for technical assistance and fruitful discussions during the study. We thank the Academy of Finland (SUNARE: Research project "Emissions from thermal insulations") for financial support, and Orion Diagnostica for providing the Hygicult ${ }^{\circledR}$ slides.

\section{References}

Adams, M.R. \& Moss, M.O. 2002. Food microbiology. The Royal Society of Chemistry, UK. 479 p.

Archibald, L.B. 1992. Quality in flax fibre. In: Sharma, H.S.S. \& Sumere, C.F. van (eds.). The biology and processing of flax. Belfast: M Publications. p. 297-309.

Donham, K.J. 1986. Hazardous agents in agricultural dusts and methods of evaluation. American Journal of Industrial Medicine 10: 205-220.

Fellows, P.J. 2000. Food processing technology. Cambridge: Woodhead publishing Ltd. $575 \mathrm{p}$.

Hakala, N. \& Hongisto, S. (eds.). 1994. Öljypellavan viljelyopas. Savonlinna: Elixi Oil Oy. 15 p.

Han, J.S. \& Rowell, J.S. 1997. Chemical composition of fibers. In: Rowell, R.M. et al. (eds.). Paper and composites from agro-based resources. USA: CRC Press. p. 83-136.

Hautala, M., Pasila, A. \& Pirilä, J. 2004. Use of hemp and flax in composite manufacture: a search for new production methods. Composites: Part A 35: 11-16.

Hepworth, D.G., Hobson, R.N., Bruce, D.M. \& Farrent, J.W. 2000. The use of unretted hemp fibre in composite manufacture. Composites: Part A 31: 1279-1283.

Hobson, R.N., Hepworth, D.G. \& Bruce, D.M. 2001. Quality of fibre separated from unretted hemp stems by decortication. Journal of Agricultural Engineering Research 78: 153-158.

Keller, A., Leupin, M., Mediavilla, V. \& Wintermantel, E. 2001. Influence of the growth stage of industrial hemp on chemical and physical properties of the fibres. Industrial Crops and Products 13: 35-48.

Koivula, M.J., Kymäläinen, H.-R., Vanne, L., Levo, S., Pehkonen, A. \& Sjöberg, A.-M. 2004. Microbial quality of linseed and fibre hemp plants during growing and harvesting seasons. Agricultural and Food Science 13: 327-337.

Koivula, M.J., Kymäläinen, H.-R., Virta, J., Hakkarainen, H., Hussein, T., Komulainen, J., Koponen, H., Hautala, M., Hämeri, K., Kanerva, P., Pehkonen, A. \& Sjöberg, A.-M. 2005. Emissions from thermal insulations - Evaluation of emissions from organic and inorganic insulations. Building and Environment 40: 803-814.

Kymäläinen, H.-R., Hautala, M., Kuisma, R. \& Pasila, A. 2001. Capillarity of flax/linseed (Linum usitatissimum L.) and fibre hemp (Cannabis sativa L.) straw fractions. Industrial Crops and Products 14: 41-50.
Kymäläinen, H.-R., Koivula, M. \& Kuisma, R. 2002. Requirements of flax, linseed and hemp fibre for insulation materials. In: Agricultural machinery, buildings and hydraulic engineering. Tartu: Estonian Agricultural University, Transactions No 215. p. 88-92.

Kymäläinen, H.-R., Koivula, M., Kuisma, R., Sjöberg, A.-M. \& Pehkonen, A. 2004. Technologically indicative properties of straw fractions of flax, linseed (Linum usitatissimum_L.) and fibre hemp (Cannabis sativa L.). Bioresource Technology 94: 57-63.

Overbeke, M. van \& Mazingue, G. 1949. Chemical study of several varieties of flax. Bull. Inst. Textile France 13: 23.

Pasila, A. 2000. The effect of frost on fibre plants and their processing. Molecular Crystals and Liquid Crystals 353: 11-22.

Ringleb, A. \& Schulz, H. 1996. Der Dämmstoff aus Lein eine ernstzunehmende Alternative. Landtechnik 51: 40-41.

Saharan, G.S. \& Singh, B.M. 1985. An analysis of environmental factors influencing linseed rust development under field conditions. Indian Phytopathology 38: 2530.

Salo, S., Laine, A., Alanko, T., Sjöberg, A.-M. \& Wirtanen, G. 2000. Validation of the microbiological methods Hygicult dipslide, contact plate, and swapping in surface hygiene control: a Nordic collaborative study. JAOAC 83: $1357-1365$.

Sankari, H. 1998. Plant development and stem yield of nondomestic fibre hemp cultivars in long-day growth conditions in Finland. Journal of Agronomy and Crop Science 181: 153-159.

Sharma. H.S.S. 1992. Utilization of flax shive. In: Sharma, H.S.S. \& Sumere, C.F. van (eds.). The biology and processing of flax. Belfast: M Publications. p. 537-543.

Sjöberg, A.-M., Sillanpää, J., Sipiläinen-Malm, T., Weber, A. \& Raaska, L. 2002. An inplementation of the HACCP system in the production of food-packaging material. Journal of Industrial Microbiology \& Biotechnology 28: 213-218.

STM 2003. Asumisterveysohje. Sosiaali- ja terveysministeriön oppaita 2003: 1. Ministry of Social Affairs and Health. Helsinki: Edita Prima Oy. 142 p.

Struik, P.C., Amaducci, S., Bullard, M.J., Stutterheim, N.C., Venturi, G. \& Cromack, H.T.H. 2000. Agronomy of fibre hemp (Cannabis sativa L.) in Europe. Industrial Crops and Products 11: 107-118.

Sultana, C. 1992. Growing and harvesting of flax. In: Sharma, H.S. \& Sumere, C.F. van (eds.). The biology and processing of flax. M Publications, Belfast. p. 83-109.

T $211 \mathrm{om}-85$. Ash in wood and pulp. TAPPI test methods 1988, vol. 1, USA.

Tavisto, M., Kortesmaa, A., Lahtinen, S., Lindstén, L., Pasila, A., Reunanen, N. \& Pehkonen, A. 2001. Flax in MFT packages. University of Helsinki, Department of Agricultural Engineering and Household Technology, Publications $6.65 \mathrm{p}$.

Vloutoglou, I., Fitt, B.D.L. \& Lucas, J.A. 1995. Periodicity and gradients in dispersal of Alternaria linicola in linseed crops. European Journal of Plant Pathology 10: 639-653. 


\title{
SELOSTUS
}

\section{Mekaanisesti jakeistetun kuituhampun ja öljypellavan korren hygieeninen laatu}

\author{
Hanna-Riitta Kymäläinen, Minna Nykter, Mikko Hautala ja Anna-Maija Sjöberg \\ Helsingin yliopisto
}

\begin{abstract}
Niinikuitu on tärkein teknisiin sovelluksiin, kuten lämmöneristeisiin ja pakkausmateriaaleihin käytettävä niinikuitukasvien jae. Niinikuitukasvien jakeiden hygieeninen laatu on tärkeää lämmöneristeissä, jotka voivat vaikuttaa sisäilman laatuun. Pakkausmateriaalit voivat olla yhteydessä esim. ruokaan, mikä korostaa hygieenisen laadun merkitystä. Tutkimuksen tavoitteena oli kartoittaa syksyllä tai keväällä korjatun, mekaanisesti jakeistetun öljypellavan ja kuituhampun hygieenistä laatua, jota kuvattiin mikrobimäärän avulla. Lisäksi tutkittiin mikrobimäärien ja tuhkapitoisuuden mahdollista korrelaatiota.

Tutkittavana oli kaksi kasvilajia, kuituhamppu ja öljypellava. Kasvit viljeltiin ja korjattiin Siuntiossa, EteläSuomessa vuosina 2002-2003. Korret korjattiin syksyllä ennen pakkasia, ensimmäisten pakkasten jälkeen tai keväällä, minkä jälkeen korret jakeistettiin mekaanisesti.
\end{abstract}

Jakeiden kokonaismikrobimäärät selvitettiin Hygicult $®$ kastolevyillä.

Jakeiden mikrobimäärät vaihtelivat $10^{3}$ ja $10^{9}$ välillä. Aikaisen pakkasen jälkeen tai keväällä korjatun kuituhampun niinikuitu sisälsi vähiten homeita, mutta talven ja kevään aikana bakteerien ja hiivojen määrä kasvoi. Mekaanisesti jakeistettu kuitu ja päistäre sisälsivät vähemmän mikrobeja kuin kokonainen korsi. Multakontaminaatiota pidetään yleisesti hygieniariskinä. Multakontaminaatio lisää korren tuhkapitoisuutta. Jakeiden tuhkapitoisuus vaihteli 1 ja $14 \%$ välillä. Niinikuitujakeen tuhkapitoisuus oli alhaisempi kuin syksyllä korjatun korren tuhkapitoisuus. Korren ja päistäreen tuhkapitoisuus laski talven aikana 1,6\%, ja keväällä korjatusta korresta erotetun kuidun tuhkapitoisuus oli niitäkin alhaisempi $(0,9 \%)$. Mikrobi- ja tuhkapitoisuuksien välillä ei havaittu korrelaatiota. 